\title{
Többlethalálozás Európában 2020.10. és 2021.18. hét között az EuroMOMO hálózat alapján
}

Excess mortality anomalies in Europe in the period of week 10 of 2020 and week 18 of 2021 based on the EuroMOMO network

\section{Összefoglalás}

A klímaváltozás a környezetben okozott jelentős változásokon keresztül az emberi egészségre is hatást Az Egészségügyi Világszervezet (WHO) fóigazgatója 2020. március 11-én minősítette a SARS-CoV-2 okozta járványt pandémiává. Világszerte igen nagyarányú COVID-19 megbetegedési és halálozási hullám következett be a SARS-CoV-2 új koronavírus járvány következtében. A járvány ideje alatt számos szerző elemezte a COVID-19 fertőzéssel kapcsolatos halálozást, az eredmények sok esetben nehezen összevethetők az eltérő mutatók és definíciók használata miatt.

Magyarország 2010 óta vesz részt az EuroMOMO hálózatban, amelynek célja a közegészségügyi-járványügyi események okozta halálozási eltérések idöbeni detektálása. A rendszer a valós idejú nyers összhalálozási adatokat dolgozza fel standardizált módszer segítségével, így a rendszerbe jelentő 23 európai ország halálozási adatai összevethetők. A közlemény bemutatja a 2020. év során és a 2021. I. negyedévében a COVID-19 világjárvány hatását a jelentő országokban a heti adatok alapján.

A járvány első, 2020. tavaszi hulláma elsősorban a nyugat-európai országokban és néhány mediterrán országban okozott igen jelentős többlethalálozást, a nyári időszakban csak néhány országban emelkedett meg kismértékben a halálozás. A második hullám a 41. héttől kezdődött és 2021. 5. hetéig tartott, a skandináv országok kivételével minden jelentő országban, eltérő heteken és eltérő mértékben okozott a közepes kategóriától az extrém magas kategóriáig (ami az átlaghoz képest több mint kétszeres heti halálozást jelentett) többlethalálozást. A járvány 3. hulláma alatt 2021. február-márciusban a legnagyobb hatást Magyarországon lehetett megfigyelni. A többlethalálozást mutató hetek után csak két országban, rövid ideig lehetett kimutatni a halálozás - a korábbi évek influenza járványmentes heteihez képest - szignifikáns csökkenését.

Az EuroMOMO rendszer által alkalmazott módszertan lehetővé teszi az országok adatainak összehasonlítását, egy-egy ország esetében a valós idejü adatok gyors értékelése jól felhasználható a döntéshozatali folyamatokban és a krízis helyzetekre való gyors reagálásban.

Kulcsszavak: EuroMOMO rendszer, többlethalálozás, alaphalálozás, időbeni trend

\section{Abstract}

The Director-General of the World Health Organization declared the SARS-CoV-2 virus related epidemic as a pandemic on $77^{\text {th }}$ March 2020. A worldwide increase of COVID-79 related morbidity and mortality has started due to the new coronavirus SARS-CoV-2. A lot of research groups analysed the COVID-79 related morta- 
lity; however, the data and results cannot be compared due to the applied different methods and variables. Hungary has provided mortality data to the EuroMOMO network since 2010. The network aims to detect timely the mortality anomalies caused by epidemics and public health threats. The network analyses real time crude total mortality data by standardized statistical method allowing the comparison of mortality of 23 reporting European countries. The paper presents the impact of COVID-79 pandemic in 2020 and in the $7^{\text {st }}$ quarter of 2021 of the reporting countries based on weekly mortality data.

The first wave of the pandemic in spring 2020 caused a very significant excess mortality mainly in the Western European and in some Mediterranean countries. During the summer 2020 medium death toll was observed in some countries. The $2^{\text {nd }}$ wave of the pandemic started on the $47^{\text {st }}$ week of 2020 , lasted to the $5^{\text {th }}$ week of 2021 and caused very high and extremely high excess mortality in almost every reporting country (meaning a more than twofold increase of the weekly mortality compared to the "baseline" mortality of the previous 5 years' identical weeks without influenza epidemic) with the exception of the Scandinavian countries on different weeks. During the $3^{\text {rd }}$ wave of the pandemic in February-March 2027 the highest mortality impact was observed in Hungary among the reporting countries. A mortality displacement meaning lower number of death cases than the baseline was observed only in two reporting countries for 2-3 weeks.

The standardized methodology of the analysis of mortality by the EuroMOMO network allows anyone to compare the data of different countries and a trend analysis within a country. The real time assessment of the mortality situation helps timely decision making and rapid responses to crisis situations.

Keywords: EuroMOMO system, excess mortality, baseline mortality, time trend

EGÉSZSÉGTUDOMÁNY
2021;65(2):4-18
HEALTH SCIENCE
Közlésre érkezett: 2021. június 77.
Submitted: 77 June 2027
Elfogadva: 2021. június 30.
Accepted: 30 June 2027
Levelezési cím/Correspondence:
Dr. Páldy Anna
Nemzeti Népegészségügyi Központ
1097 Budapest, Albert Flórián út 2-6.
E-mail: paldy.anna@nnk.gov.hu

\section{Bevezetés}

Az Egészségügyi Világszervezet (WHO) föigazgatója 2020. március 11-én minősítette a SARS-CoV-2 okozta járványt pandémiává. Világszerte igen nagyarányú COVID-19 megbetegedési és halálozási hullám következett be a SARS-CoV-2 új koronavírus járvány következtében. Európában három hullámot figyelhettünk meg, 2020 tavaszán, november-decemberben, vala- mint 2021. január-április között. Az országok különböző elvek alapján követik nyomon a járvány halálos áldozatainak számát. Egyes országok a teszttel megerősített COVID-19 megbetegedésben elhunytakat tekintik a járvány áldozatainak, míg más országokban a tünetek alapján minősítik az eseteket?

A pandémia hatását többféle módon lehet mérni a két fő kimenetel, a jelentett incidencia és a halálozás mutatók felhasználásával. Mindkét mutatót többféle módon lehet vizsgálni, beleértve az időbeli változást és a kumulációt. Mindkét mutató esetében nagyon fontos az eset definíció, amit a tesztelés mértéke befolyásol. A halálozási adatok nagymértékben függnek az adatgyűjtés módjától. Vannak országok, ahol külön rendszerben gyűjtik a kórházban és az idős otthonokban elhunytak adatait abból a célból, hogy gyorsan tudjanak információt adni a növekvő trendekről. Emellett léteznek rutin regisztrációs rendszerek, amelyek keretében nagyobb biztonsággal állapítják meg a halálokokat. A halálokok megállapítása is többféleképpen történik, esetleg országon belül is változhat, hogyan veszik figyelembe a COVID-19 fertőzés szerepét a halálozásban: azaz, ha a beteg valamikor COVID-19 pozitív teszteredményt mutatott; vagy a halál beállta előtt egy meghatározott időszakban állapították meg a pozitivitást, vagy nem volt pozitív teszteredménye, de a tünetei COVID-19 megbetegedésre utaltak². Spa- 
nyolországban a definíció szerint polimeráz láncreakción alapuló (PCR) teszttel meghatározott pozitivitást fogadnak el kizárólag kórházi halálozás esetén annak ellenére, hogy magas az idősotthonokban bekövetkezett COVID-19 miatti halálozás is. Ezzel szemben Belgiumban még a gyanús eseteket is COVID-19 halálesetnek definiálják. A Belgiumban regisztrált többlethaláleseteknek körülbelül fele idősotthonokban történt, de csak 26\% idősotthoni halálozás esetében bizonyították a COVID-19 fertőzést, ami az esetek túljelentését eredményezhette a többi országhoz képest² ${ }^{2}$. Feltételezhető tehát, hogy sok halálesetet helytelenül COVID-19 megbetegedésnek tulajdonítottak, de az ellenkező helyzet is elképzelhető, amikor is az elsődleges halálok a COVID-19 megbetegedés volt² .

A WHO 2020. áprilisban közzétett egy útmutatót ${ }^{3,4}$, amelyben meghatározza, hogy a halálokok közül melyet kell a COVID-19 miatti halálozásnak kódolni; ennek ellenére továbbra sem egységes az esetek meghatározása. A COVID-19 megbetegedéssel összefüggő halálesetek adatainak közlését a gyakorlatban világszerte nagy média és politikai érdeklődés övezi. A jelentett adatok részint a halálok meghatározása, részint a különböző mutatók alkalmazása - sok esetben nyers számokat közölnek arányok, vagy még inkább kor szerint standardizált mutatók helyett ${ }^{5}$, nagyon megnehezíti az adatok helyes értelmezését, továbbá az összehasonlításokat.

A nemzetközi irodalomban néhány kutatócsoport 6,7,8,9 megállapította, hogy a SARS-CoV-2 pandémia halálozásra kifejtett hatását legjobban a többlethalálozások alapján lehet értékelni. A módszernek vannak előnyei és hátrányai is, mivel a nyers halálozási adatok magukban foglalják azokat a haláleseteket is, amik nincsenek összefüggésben a COVID-19 fertőzéssel, hanem például a túlterhelt egészségügyi ellátó rendszerrel; másrészt alulbecsülhetik a COVID-19 fertőzéssel kapcsolatos halálozásokat egyéb halálokok, mint például a közlekedési balesetek miatt.

A fenti korlátozó tényezők ellenére a többlethalálozási mutató lehetőséget biztosít arra, hogy egy adott időszakban és területen össze lehessen hasonlítani a halálozás alakulását az arra az időszakra vonatkozó várt halálesetek alakulásával. Ez utóbbi meghatározása is különböző módon történhet: pl. az előző egy vagy több év, azonos időszakra vonatkozó átlag halálozása (pl. az EuroStat ${ }^{10}$ négy évet, a Központi Statisztikai Hivatal az elmúlt évet veszi alapul" a gyors értékelésnél). Problémát jelenthet a várt értékek meghatározásában, ha a megelőző évek identikus időszaka alatt is volt valamilyen esemény, ami megnövelte a halálozást, pl. a 2017, 2018. évi influenzajárványok alatti többlethalálozás. Az adott helyzet legszakszerübb értékelése a járványmentes időszakok halálozásának figyelembe vételével valósítható meg, ahogyan ez az EuroMOMO rendszerben történik ${ }^{12}$.

Az összes halálok miatti haláleseteket magában foglaló többlethalálozás segítségével lehet kezelni az országok által különböző módon meghatározott és jelentett COVID-19 esetekből származó különbségeket és a halottvizsgálati bizonyítványon a halálok nem pontos meghatározása miatti különbségeket. A többlethalálozási mutató alkalmazása esetén - feltételezve, hogy az egyéb halálokok miatti halálozás incidenciája az idők folyamán állandó -, a többlethalálozásokat úgy tekinthetjük, mint a közvetlenül, vagy közvetve a COVID-19 megbetegedéssel kapcsolatos különféle kockázati tényezők eredményeként bekövetkező haláleseteket. A többlethalálozás kor és populáció méret szerint standardizálható, így még pontosabban lehet összehasonlítani az országokat. Az 1. ábrával szemléltetni szeretnénk a többlethalálozást meghatározó tényezőket, melyek igen összetettek. A COVID-19 esetek azonosításán kívül meghatározóak az egyéni szociális és társadalmi tényezők, az egészségügyi ellátó rendszer müködése, igénybevétele, a lakosság morbiditási és mortalitási viszonyai stb. A jelen közleményben nem kívánjunk ezen tényezők szerepét részletesen vizsgálni.

Célunk az EuroMOMO rendszer heti összesített és országonkénti többlethalálozási eredményeinek leíró bemutatása, különös tekintettel a járvány harmadik hulláma hazai jellegzetességeinek ismertetésére. 


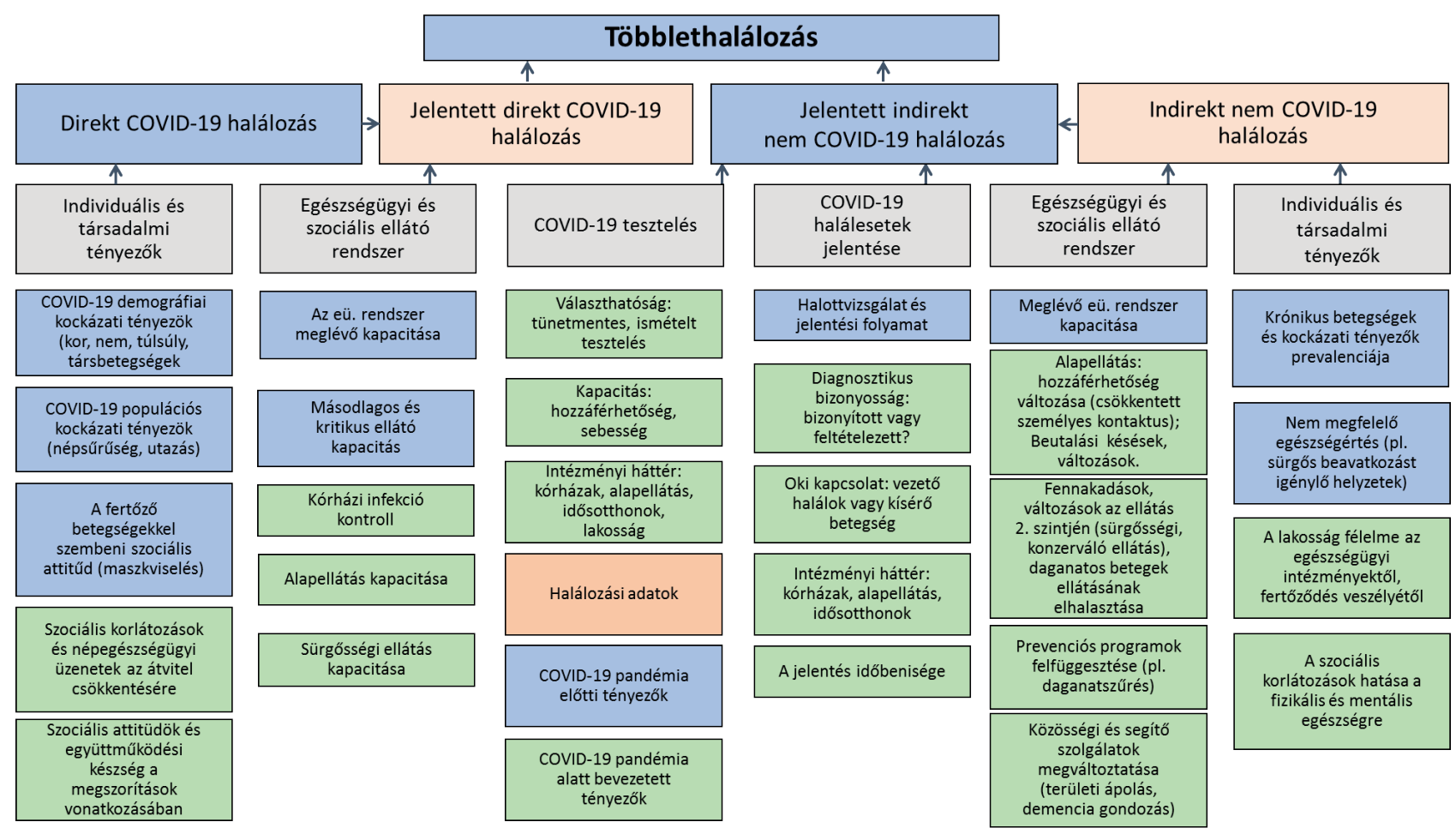

7. ábra: A többlethalálozást befolyásoló tényezők²

\section{Anyag és módszer}

Az EuroMOMO rendszer múködését korábbi közleményünkben részletesen ismertettük ${ }^{13}$. A továbbiakban néhány fontos jellegzetességet emelünk ki.

Az EuroMOMO hálózat a következő adatokat használja és elemzi:

- A résztvevő országok hetente megküldik a koppenhágai központba a hivatalos, minőségellenőrzött heti aggregált halálozási adatbázist - összes halálozás nemi és korcsoportos bontásban (a hazai adatszolgáltató a Belügyminisztérium Nyilvántartások Vezetéséért Felelős Helyettes Államtitkárság Személyes Ügyfélszolgálati és Okmányügyeleti Főosztály Ügyeleti Ügyfélszolgálati és Támogató Osztálya, az adatbázist előkészíti, hazai szinten értékeli a Nemzeti Népegészségügyi Központ).

- A heti jelentési késések (halál napja és a regisztráció napja közötti eltérés) elemzése összes halálozás, továbbá nemi és korcsoportos bontásban.

- A várt heti halálozás (naptár alapú) és a heti adatok összevetése országos szinten korcsoportos bontásban.
- A megállapított heti többlethalálozás jelentése országonként, összesítve és korcsoportonként.

A statisztikai feldolgozás során szórásra (diszperzióra) korrigált általános lineáris Poisson regressziós modellt ( $\mathrm{glm})$ alkalmaznak. A modellt valós történelmi, maximum 5 éves megelőző periódusra illesztik, amelyből kizárják a késedelmes regisztráció miatti periódust, továbbá a nagyobb járványok időszakait (2017, 2018 - influenzajárványok, 2020 tavaszi COVID-19 első hullám). Az algoritmus segítségével meghatározható a heti megfigyelt, várt halálozás, és többlethalálozás összesítve és korcsoportonként, az alaphalálozás standard deviációja (Z-score), korrigálható a késedelmes jelentésből fakadó adathiány.

\section{Eredmények}

A heti halálozások leíró jellegú bemutatása a 23 jelentő európai ország adatai alapján történik az EuroMOMO honlapon közzétett ábrák és grafikonok segítségével. 2020 első heteiben az influenzajárvány idején, ellentétben a korábbi években tapasztaltakkal, a ha- 
lálozás a jelentő országok összesített adatai szerint is csak két héten emelkedett meg minimális mértékben (2. ábra). Ezt követően a 10. héttől meredek növekedés látható a 22. hétig, majd a 30-34. hétig ismét növekedett a többlethalálozás, a 39. héten kezdődött és 2021. 8. hetéig tartott az igen jelentős halálozási többlet az összesített adatokban.

A növekedés kezdetén, 2020. 11. héten az összesített halálozás eltérése meghaladta a 4-szeres Z-score értékét $(5,53)$, a csúcsot a 14 . héten érte el, az eltérés Z-score értéke meghaladta a 49-et. A nyári kisebb hullám idején a csúcsot a 33. héten érte el, a Z-score 13,5 volt. A harmadik hullám elhúzódó jellegű volt, csúcsát 2021. 3. hetén érte el, a Z-score 20,9-es értéket mutatott (3. ábra). 2021. február-márciusban a jelentő országok öszszességére vonatkoztatva alacsony többlethalálozást lehetett kimutatni, a csúcsot a 16. héten érte el, az eltérés Z-score értéke 6,55 volt.
A 4. ábrán bemutatott térkép szerint a 2020. tavaszi COVID-19 járvány első hulláma alatt a legmagasabb többlethalálozás a 14. héten fordult elő, amikor a legsötétebb színnel jelzett nyugat-és dél-európai országokban az alaphalálozás standard deviációja értékének 15-szörösét regisztrálták.

Az 5. ábra a 2020. nyár végi időszak alatti maximális többlethalálozást mutatja a 33. heti térképen. A legmagasabb többlethalálozás ez idő alatt Belgiumban volt megfigyelhető.

A 6. ábra a harmadik hullám csúcsidőszakát (2021. 3. hét) mutatja be, amikor extrém magas volt a halálozási többlet az Egyesült Királyságban és Spanyolországban

A 7. ábra a 2021. 16. hét többlethalálozását ábrázolja, ami az összesített adatok szempontjából a legmagasabb többlethalálozást mutatta, Franciaországban és Ukrajnában magas Z-score értéket detektáltak.

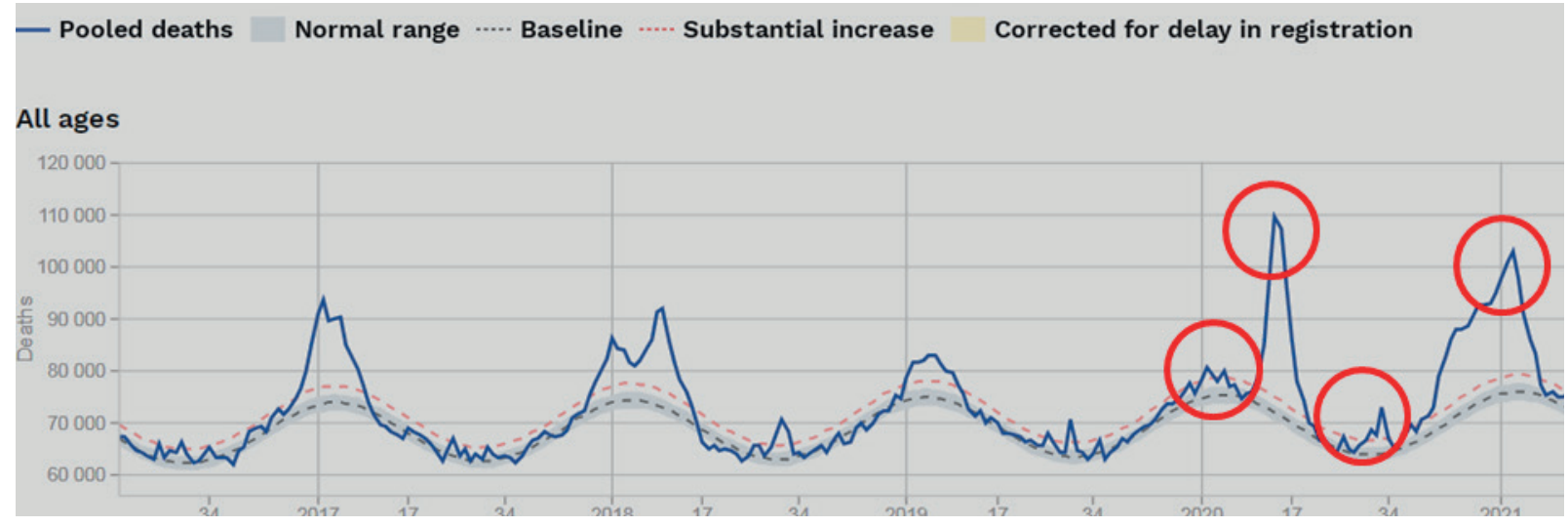

2. ábra: Összesített heti halálozás az EuroMOMO hálózatnak adatot szolgáltató országokban 2016-tól (heti halálesetek összege)

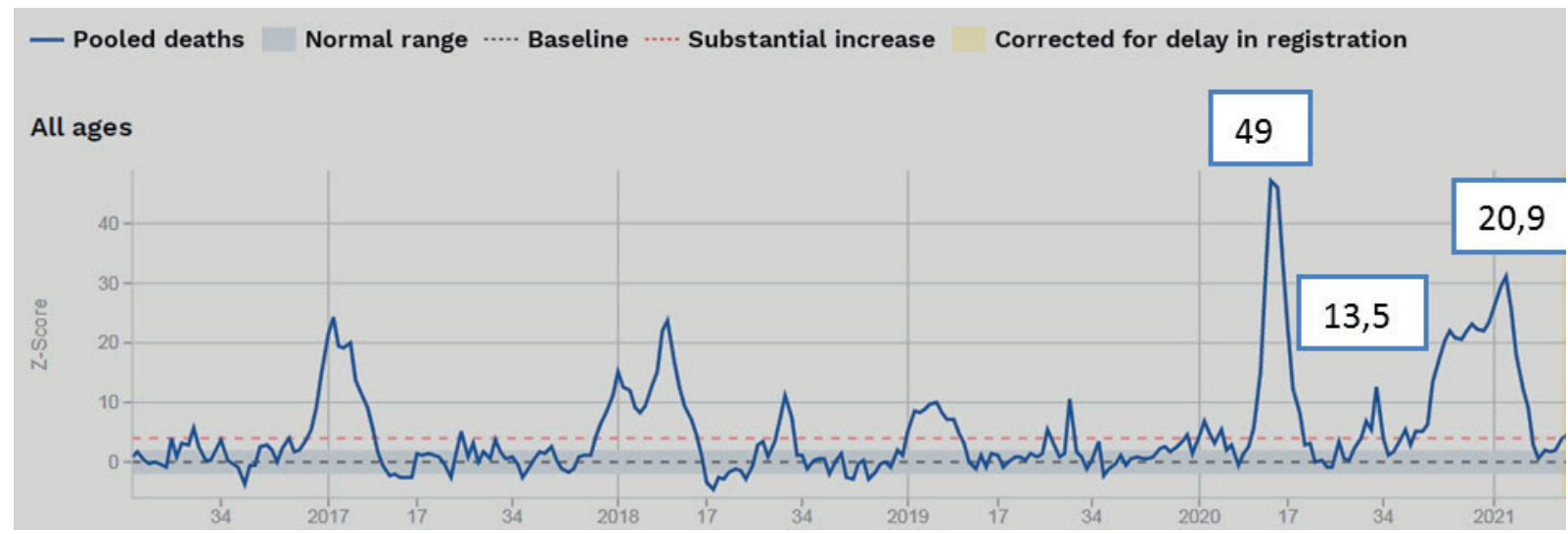

3. ábra: Összesített heti halálozás eltérés az EuroMOMO hálózatnak adatot szolgáltató országokban 2016-tól (Z-score) 


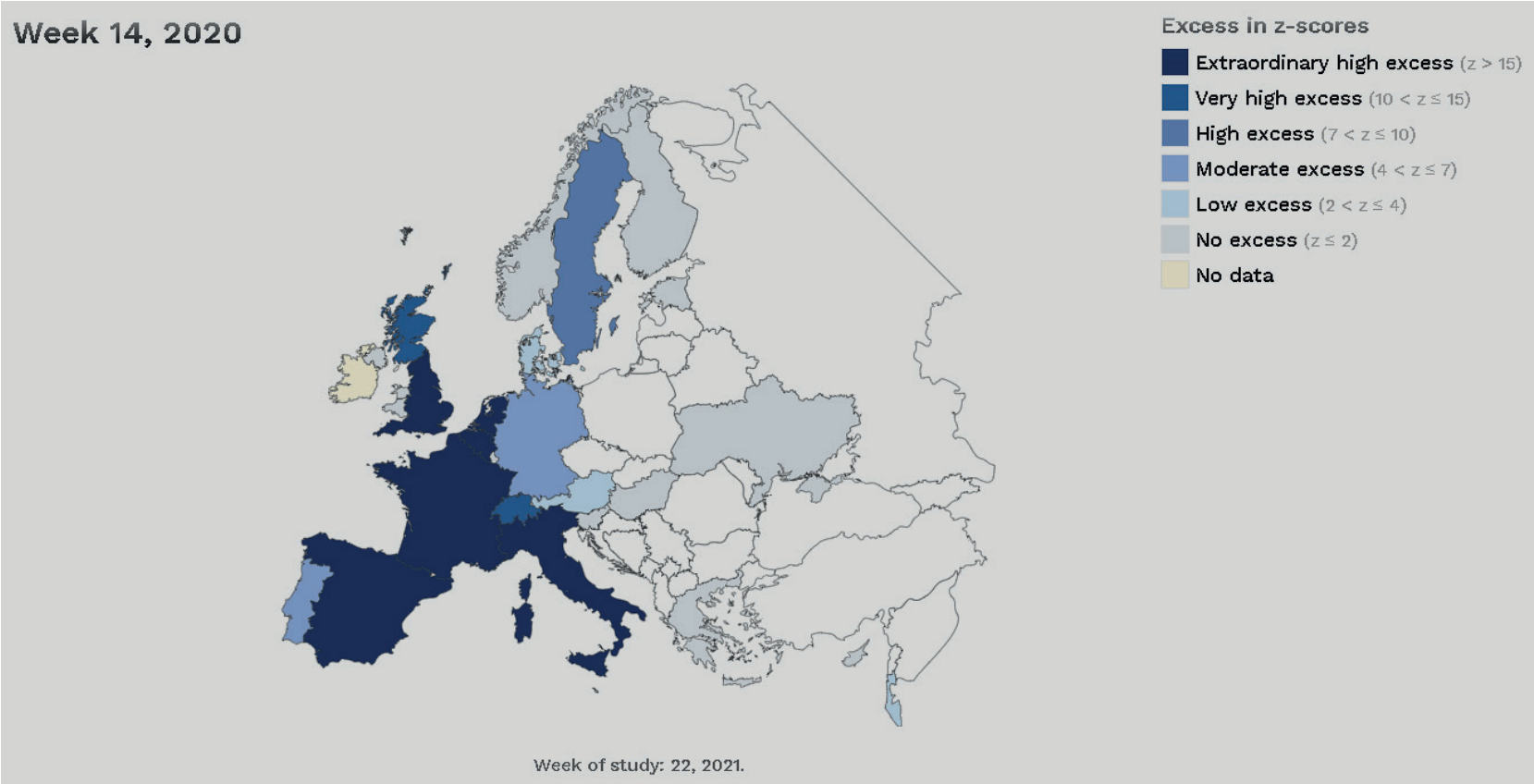

4. ábra: Összhalálozási többlet Z-score érték kategóriákban kifejezve az EuroMOMO hálózatnak adatot szolgáltató országokban 2020. 14. hét

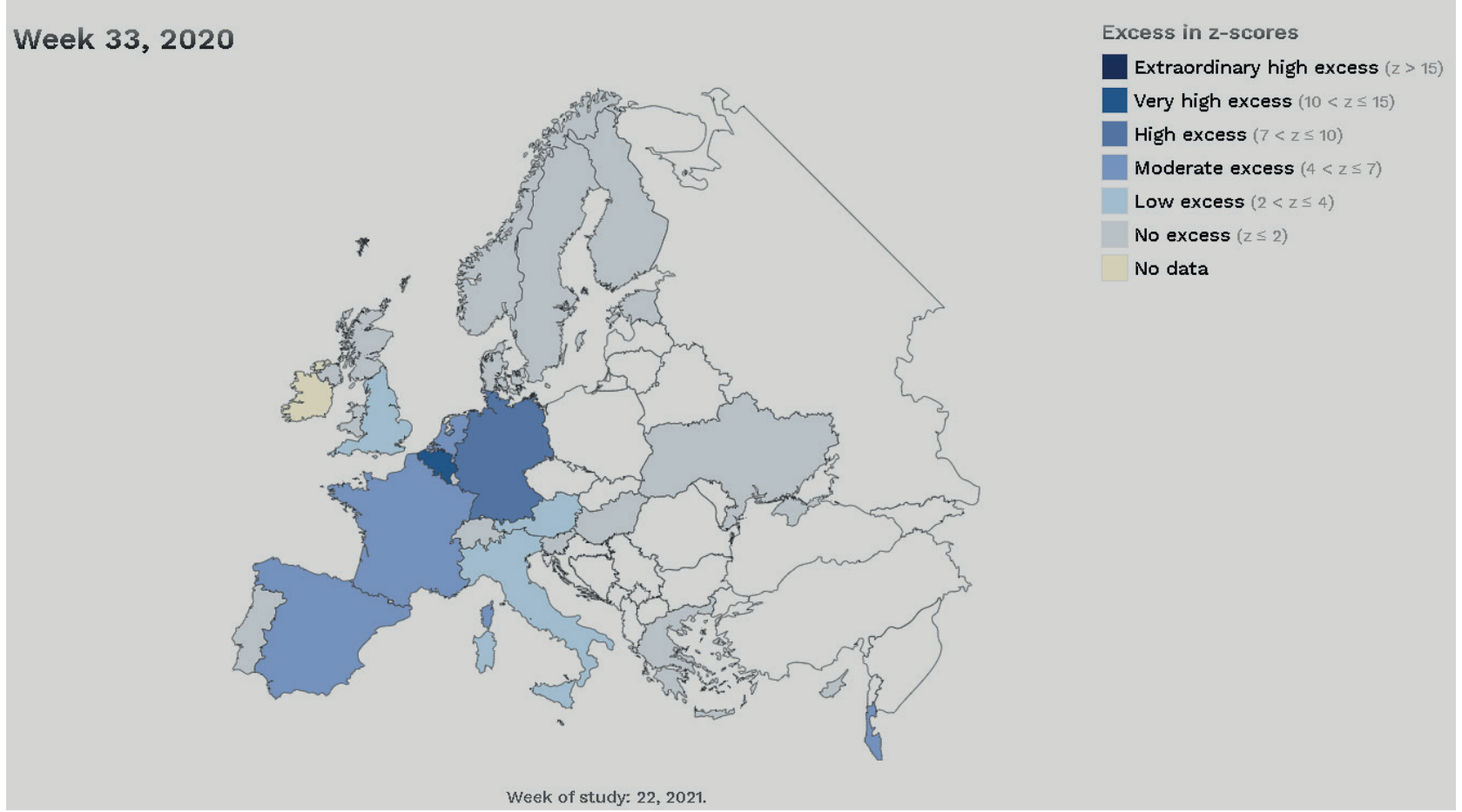

5. ábra: Összhalálozási többlet Z-score érték kategóriákban kifejezve az EuroMOMO hálózatnak adatot szolgáltató országokban 2020. 33. hét 


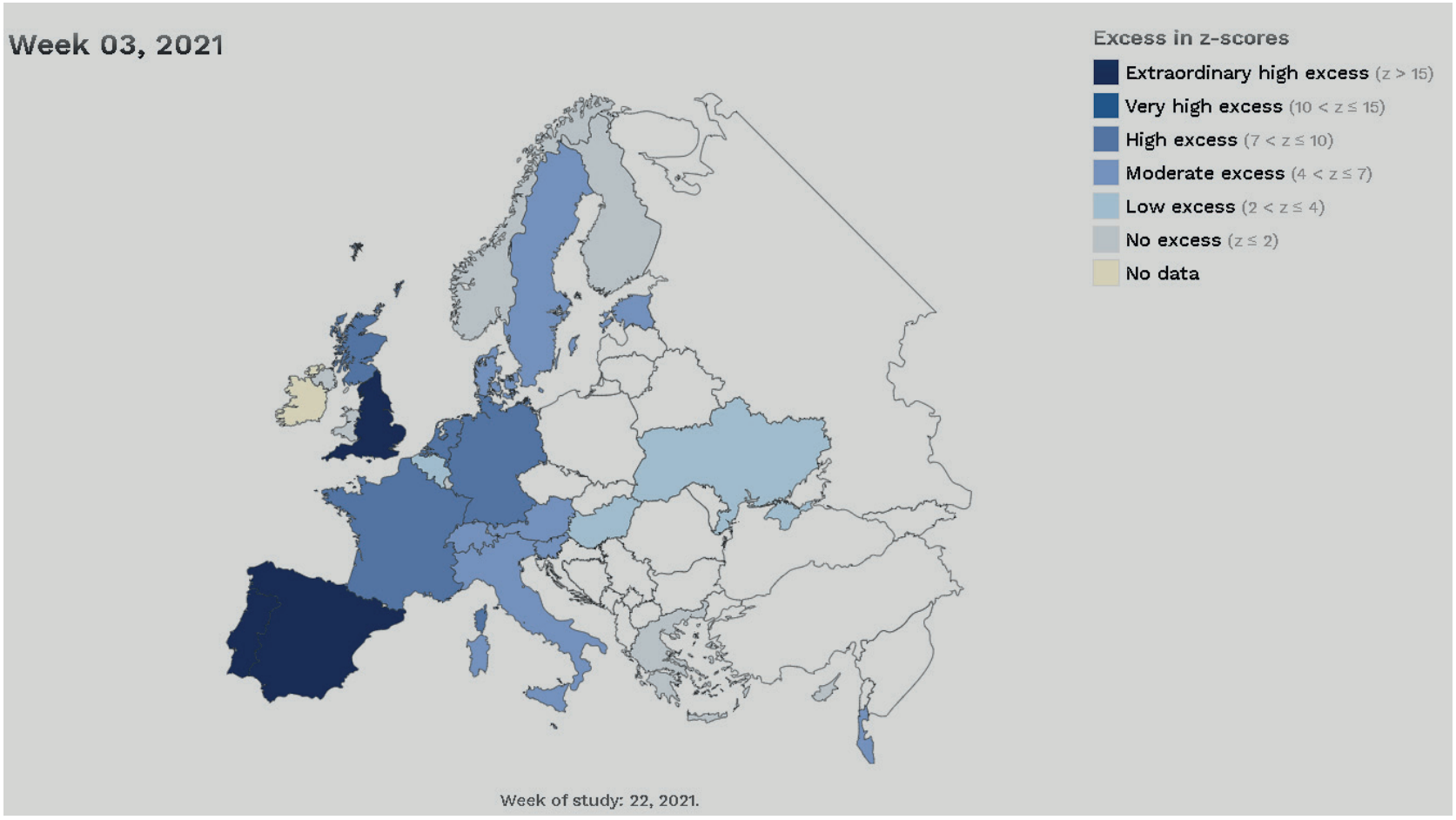

6. ábra: Összhalálozási többlet Z-score érték kategóriákban kifejezve az EuroMOMO hálózatnak adatot szolgáltató országokban 2021. 03. hét

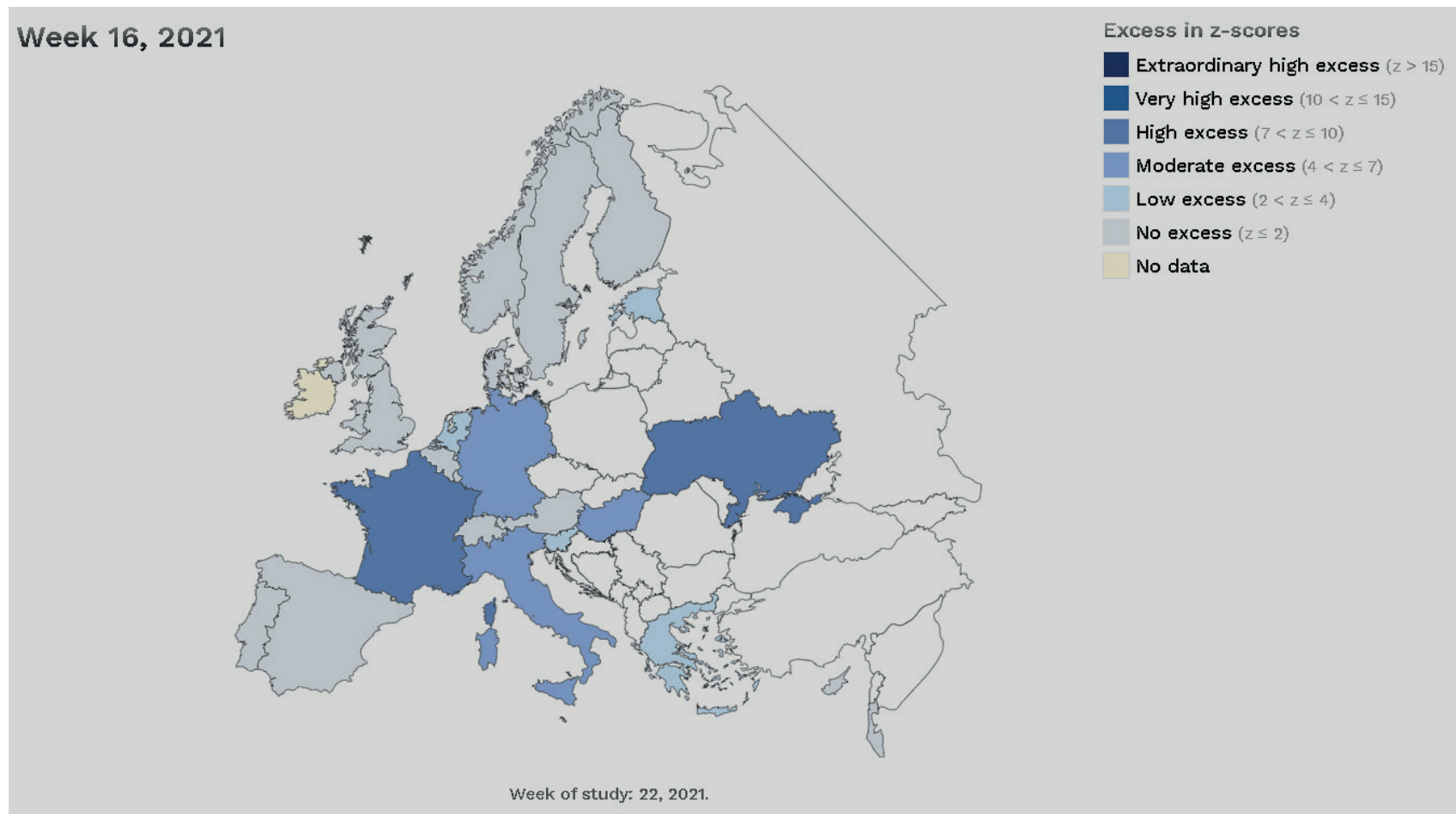

7. ábra: Összhalálozási többlet Z-score érték kategóriákban kifejezve az EuroMOMO hálózatnak adatot szolgáltató országokban 2021. 16. hét 
Az 1. táblázat összefoglalja az EuroMOMO rendszerbe jelentő 23 ország heti halálozási eltéréseit 2020. 10. hete és 2021. 18. hete közötti időszakban. Az országokat földrajzi elhelyezkedés szerint csoportosítottuk. Látható, hogy a SARS-CoV-2 pandémia első, 2020. tavaszi hulláma idején a többlethalálozás Nyugat és Dél-Európában volt igen jelentős, illetve Svédországban is ki lehetett mutatni. A legnagyobb mértékű többlethalálozást Spanyolországban figyelhettük meg 2020. 14. hetén, amikor az arra a hétre vonatkozó alaphalálozás standard deviációjához képest az eltérés majdnem 45-szörös volt. Ilyen nagyfokú többletet a későbbiek során nem lehetett kimutatni egyetlen országban sem.

A tavaszi hullám lecsengése után a nyár végén, a 30. héttől kezdett ismét emelkedni a halálozás, elsősorban a mediterrán és egyes nyugat-európai országokban, de az eltérés mértéke jóval kisebb volt, mint tavaszszal. A legnagyobb eltérést Belgiumban regisztrálták a 33. héten (Z-score: 11,6). A 2. hullám a 41. héttől kezdett erősödni a skandináv országok kivételével a jelentő országokban néhány hetes eltérésekkel. A 44-51. hét között elsősorban Franciaországban, Belgiumban, Svájcban, Ausztriában, Szlovéniában, Magyarországon és Olaszországban volt igen jelentős a többlethalálozás, a legmagasabb eltérést a 45 . héten Belgiumban regisztrálták (Z-score: 18,64). A többlethalálozás a 2020. 53. és 2021. 5. hete között ismét növekedett, elsősorban az Egyesült Királyságban, Portugáliában és Spanyolországban, a legmagasabb eltérést Portugáliában rögzítették 2021. 3. hetén (Z-score: 24,08). 2021. 7. héttől kezdve a jelentő országok többségében csökkent, vagy megszűnt a halálozási többlet, kivéve Franciaországot, Észtországot, Magyarországot, Ukrajnát, Olaszországot és Görögországot. A 7-18. hét közötti időszakban a legmagasabb heti eltéréseket Magyarországon lehetett megfigyelni, a maximumot a 12. héten regisztrálták (Z-score:17,54).

Vizsgáltuk azt is, hogy megfigyelhető-e valamely országban a halálozási többletet követő, hosszabb ideig fennálló szignifikáns halálozás csökkenés: ezt csak az első hullámot követően Spanyolországban lehetett megfigyelni három héten keresztül a 23-25. héten, a minimumot a 24. héten érte el (Z-score: -3,29). Norvégia esetében meg kell említeni, hogy a vizsgált időszakban egyetlen héten sem volt szignifikáns halá- lozási többlet, viszont két időszakban is ki lehetett mutatni szignifikáns csökkenést (2020. 20-23. hét és 2021. 5-13. hét között).

A 8. ábra a magyarországi adatokat mutatja be a teljes lakosságra vonatkozóan (mind a haláleset számokat, mind az átlagtól való eltérést Z-score-ban kifejezve 2014. 1. - 2021. 17. hét között). A grafikonokról látható, hogy hazánkban is meg lehetett figyelni többlethalálozást a korábbi években: 2014/15 telén, a kétszeres Z-score érték felett volt 10 héten át (3 - 13. hét). A következő jelentős többlethalálozást mutató időszak 2016/2017 tél-kora tavaszi időszak volt, ami szintén egybeesett az influenzajárvánnyal, hasonló kép figyelhető meg 2017/2018 és 2018/19 kora tavaszán. Az ábrákról a nyári nagy hőhullámok hatása is látható, pl. 2015-ben az öt hőhullám alatt több mint 1800 többlethalálesetet regisztráltunk, a 31. és 33. héten lehetett kimutatni a 2-szeres Z-score feletti többlethalálozást, elsősorban a 65 éven felüliek körében ${ }^{13}$.

Hazánkban a COVID-19 járvány idején 2020. 43. hetén lehetett először kimutatni szignifikáns növekedést a halálozásban (Z-score: 3,33) (8. ábra). A legmagasabb eltérést a 49. héten lehetett megfigyelni (Z-score: 12,87), majd fokozatos csökkenés következett. A legfrissebb adatok szerint a 2. és 3. hullám közötti időszakban minden héten szignifikánsan magasabb volt a halálozás, mint az előző évek járványmentes heti átlaga, a legalacsonyabb eltérést az 5 . héten lehetett megfigyelni (Z-score: 2,02). A 7. héttől ismét emelkedni kezdett a halálozás, az eltérés Z-score értéke 2,80. A 9. héttől igen jelentős mértékú lett a többlethalálozás, a Z-score 5,42, majd a 12. héten érte el a csúcsot (17,54-szeres eltérés a megelőző évek influenzajárvány mentes hetek átlagának szórásától). Ezután csökkenés figyelhető meg, a 15. héten már 8,36 a Z-score értéke, a 16. héten a Z-score 5,18 . A 17. héten már jelentősebb csökkenés észlelhető, a Z-score 3,71, a 18. héten már nem szignifikáns az eltérés (Z-score: 1,31).

A 9. ábra a 2021. 13. heti többlethalálozást mutatja be az európai térképen. Látható, hogy a 13. héten (március utolsó hete) hazánkban extrém magas volt a többlethalálozás a járvány harmadik hulláma során, és csak további három országban (Észtország, Franciaország, Olaszország) volt magas vagy közepesen magas a halálozási többlet. 
Népegészségügy - Eredeti közlemény / Public health - Original article

1. táblázat: Az EuroMOMO rendszerbe jelentő országok többlethalálozás eltérése (Z-score) 2020. 10. hét és 2021. 18. hét között

\begin{tabular}{|c|c|c|c|c|c|c|c|c|c|c|c|c|c|c|c|c|c|c|c|c|c|c|c|}
\hline hetek & GBR & FRA & BEL & NED & LUX & GER & SUI & DEN & NOR & SWE & FIN & EST & AUT & SLO & HUN & UKR & POR & ESP & ITA & CYP & MLT & GRE & IZR \\
\hline 10 & & 1,56 & 0,04 & & & 1,60 & & & & & & & 1,98 & & & & & & 2,46 & & & & \\
\hline 11 & & 3,15 & 0,61 & 2,07 & & 2,38 & 1,56 & 0,31 & & & & & 1,64 & & & & 1,77 & 4,63 & 5,95 & & 2,04 & & \\
\hline 12 & 4,05 & 8,45 & 4,45 & 6,39 & & 2,37 & 4,45 & 1,86 & & & & & 3,39 & & & & 2,71 & 17,65 & 10,58 & & 3,28 & & \\
\hline 13 & 12,25 & 16,48 & 11,63 & 15,04 & 2,44 & 2,65 & 6,69 & 1,38 & & 4,06 & & & 2,43 & & & & 4,07 & 41,77 & 13,71 & & & & \\
\hline 14 & 26,87 & 26,57 & 20,62 & 21,39 & 1,10 & 5,07 & 11,71 & 2,58 & & 9,62 & & & 3,76 & & & & 5,35 & 44,99 & 15,68 & & & & 2,48 \\
\hline 15 & 34,19 & 22,64 & 23,76 & 20,93 & 2,90 & 5,21 & 7,61 & 2,44 & & 12,93 & 2,67 & & 3,42 & & & & 5,19 & 33,82 & 12,48 & & & & \\
\hline 16 & 29,72 & 15,55 & 18,24 & 14,86 & & 2,92 & 6,46 & 0,97 & & 12,82 & 0,99 & & 2,00 & & & & 3,00 & 20,49 & 7,91 & & 2,77 & & \\
\hline 17 & 24,15 & 6,10 & 11,54 & 11,21 & & 1,70 & 2,59 & & & 9,62 & 2,35 & & & & & & 2,39 & 10,15 & 6,28 & & & & \\
\hline 18 & 16,69 & 0,74 & 4,26 & 5,93 & & & & & & 9,62 & 2,71 & & & & & & & 4,52 & 4,16 & & & & \\
\hline 19 & 11,53 & & 4,49 & 1,84 & & & & $-0,49$ & & 9,28 & 0,99 & & & & & & & 2,44 & 3,05 & & & & \\
\hline 20 & 6,61 & & 0,61 & & & & & $-2,33$ & $-2,65$ & 6,90 & 2,20 & & & & & & & & 1,31 & & & & \\
\hline 21 & 4,70 & & & & & & & & $-2,74$ & 6,26 & & & & & & & & & & 4,02 & & & 3,14 \\
\hline 22 & 2,41 & & & & & & & & $-2,34$ & 1,86 & & & & & & & 3,80 & & & & & $-2,26$ & \\
\hline 23 & 1,77 & & & & & & & & & 3,99 & & & & & & & & $-2,31$ & & & & & \\
\hline 24 & & & & & & & & & & 3,89 & & & & & & 3,66 & & $-3,29$ & & & & & \\
\hline 25 & & 2,60 & & & & & & & & 3,24 & 2,51 & & & & & & & $-2,02$ & & & & & \\
\hline 26 & & & & & & & & & & 3,22 & & & & 2,64 & & & 2,17 & & 2,03 & & & & \\
\hline 27 & & & & & & & & & & 1,62 & & & & & & & 1,56 & & & & & 2,92 & \\
\hline 28 & & & $-2,59$ & & & & & & & & & & & & & & 3,76 & 2,10 & & & & & \\
\hline 29 & & & & & & & & & & & & & & & & & 8,63 & 1,59 & & & & & \\
\hline 30 & & & & & & 1,65 & & & & & & & & & & & 6,14 & 2,76 & & & & & \\
\hline 31 & & 1,96 & & & & 2,87 & & & & & & 2,21 & & 2,11 & & & 3,64 & 6,16 & 2,20 & & & 3,30 & 4,28 \\
\hline 32 & & 1,40 & & & 2,14 & 3,02 & & & & & & & & & & & 2,22 & 5,66 & 1,85 & & & 2,19 & 2,16 \\
\hline 33 & 3,41 & 5,57 & 12,59 & 6,38 & & 8,06 & & & & & & & 2,16 & & & & & 4,66 & 2,28 & & 2,41 & & 4,37 \\
\hline 34 & & 0,40 & 4,50 & 2,28 & & 3,02 & & & & & & & & & & & & 3,40 & & & 2,52 & & 3,44 \\
\hline 35 & & & 0,11 & & & & & & & & & & & & & & & 3,52 & & & & & 3,01 \\
\hline 36 & & & & & & & & & & & & & & & & & & 2,64 & & & & & 2,78 \\
\hline 37 & & 2,32 & & & & & & & & & 3,01 & & & & & & 3,63 & 3,77 & & & & & 4,38 \\
\hline 38 & & 4,35 & & & & & & & & & & 2,19 & & 2,48 & & & 2,23 & 4,29 & 2,10 & & 2,38 & & 5,24 \\
\hline 39 & & & & 1,77 & & & & & & & & 2,98 & & & & 2,26 & & 3,75 & & & & & 5,56 \\
\hline 40 & & 3,57 & & 2,75 & & & & & & & & 1,48 & & & & 3,17 & 2,07 & 3,79 & & & & & 4,86 \\
\hline 41 & & 2,99 & & 2,71 & & & & & & & & & & & 1,83 & 4,48 & 1,96 & 5,55 & 2,20 & & & & 7,17 \\
\hline 42 & 2,15 & 3,65 & 2,11 & 4,65 & & & & & & & & & & 2,49 & 3,43 & 5,23 & 2,45 & 5,00 & 3,70 & & & & 5,99 \\
\hline 43 & 3,17 & 9,37 & 7,68 & 6,84 & & 2,57 & 4,14 & & & & & & 3,26 & 5,42 & 5,16 & 7,14 & 2,38 & 8,86 & 7,76 & & & & 4,78 \\
\hline 44 & 4,23 & 11,61 & 14,73 & 9,02 & & 2,14 & 8,07 & & & & & & 4,56 & 8,35 & 6,42 & 7,49 & 4,68 & 9,08 & 10,80 & & 2,84 & & 1,35 \\
\hline 45 & 4,95 & 14,20 & 18,64 & 7,62 & 2,77 & 2,80 & 14,76 & & & & & & 6,05 & 9,19 & 9,31 & 7,19 & 5,51 & 11,66 & 13,64 & & 2,40 & 2,07 & \\
\hline 46 & 5,53 & 13,49 & 15,55 & 7,16 & 3,01 & 3,88 & 15,84 & & & & & & 9,73 & 12,99 & 12,29 & 6,80 & 7,01 & 9,85 & 14,18 & & 3,34 & 3,55 & $-2,35$ \\
\hline 47 & 5,41 & 10,99 & 12,51 & 4,16 & 2,99 & 4,40 & 15,69 & & & 3,30 & & & 11,44 & 12,28 & 11,72 & 7,16 & 6,44 & 8,08 & 12,81 & & 2,38 & 5,59 & \\
\hline 48 & 5,29 & 9,15 & 9,10 & 4,60 & 3,55 & 6,27 & 14,67 & & & 2,36 & & & 11,41 & 14,05 & 12,21 & 6,03 & 6,07 & 6,84 & 12,77 & & 2,88 & 6,46 & \\
\hline 49 & 5,13 & 8,81 & 6,37 & 5,50 & 2,47 & 8,63 & 15,36 & & & 4,69 & & & 12,47 & 14,05 & 12,67 & 5,47 & 7,21 & 6,58 & 11,37 & & 3,84 & 6,42 & \\
\hline 50 & 6,13 & 8,31 & 7,18 & 6,06 & 3,59 & 10,78 & 15,74 & 1,21 & & 4,07 & & & 11,66 & 12,87 & 11,92 & 5,83 & 8,67 & 5,93 & 9,24 & & 3,42 & 5,05 & \\
\hline 51 & 5,73 & 6,75 & 6,26 & 8,71 & 2,23 & 11,84 & 14,91 & 4,96 & & 6,26 & & 1,55 & 8,44 & 10,74 & 9,17 & 4,43 & 7,31 & 4,82 & 9,10 & & 4,05 & 3,92 & \\
\hline 52 & 8,05 & 5,49 & 4,72 & 8,00 & 2,81 & 12,91 & 13,77 & 3,60 & & 6,22 & & 2,21 & 6,41 & 9,08 & 9,10 & 3,40 & 6,01 & 3,25 & 5,96 & & 4,38 & 2,38 & \\
\hline 53 & 10,56 & 6,32 & 2,73 & 10,01 & 0,82 & 12,38 & 11,29 & 4,53 & & 6,56 & & 2,16 & 4,68 & 8,05 & 7,00 & 2,62 & 8,98 & 4,85 & 6,80 & & 2,05 & 2,23 & 3,36 \\
\hline 1 & 15,99 & 7,71 & 2,78 & 10,10 & & 10,93 & 9,38 & 3,41 & & 5,64 & & 2,79 & 3,82 & & 4,77 & & 14,77 & 8,20 & 6,11 & & 2,26 & & 4,69 \\
\hline 2 & 20,23 & 7,42 & 1,90 & 7,26 & & 10,10 & 7,36 & 3,38 & & 5,11 & & 3,44 & 3,85 & & 4,64 & & 20,92 & 13,35 & 7,00 & & 1,33 & & 5,40 \\
\hline 3 & 20,45 & 9,35 & 2,24 & 7,26 & & 9,21 & 6,80 & 4,64 & & 4,54 & & 4,18 & 4,35 & & 3,39 & 2,14 & 24,08 & 17,18 & 6,35 & & 4,30 & & 5,71 \\
\hline 4 & 16,95 & 7,96 & 1,98 & 5,87 & & 6,39 & 4,16 & 3,04 & & 2,31 & & 1,51 & 3,55 & & 2,16 & & 22,11 & 15,82 & 6,53 & & 2,10 & & 6,08 \\
\hline 5 & 11,12 & 7,61 & & 5,31 & & 4,64 & & 2,99 & $-2,10$ & & & & 2,48 & & 2,10 & & 15,67 & 11,77 & 4,65 & & & & 5,15 \\
\hline 6 & 7,64 & 6,68 & & 4,39 & & 3,11 & & 0,76 & & & $-2,20$ & 2,96 & 1,13 & & 2,14 & & 10,66 & 7,25 & 2,65 & & 1,98 & & 3,75 \\
\hline 7 & 5,90 & 6,77 & & 4,26 & & 2,29 & & & $-2,59$ & & & 1,24 & & & 2,54 & & 5,92 & 3,84 & 4,59 & & 3,55 & & 1,82 \\
\hline 8 & 0,47 & 4,54 & & 1,23 & & & & & $-2,76$ & & & 4,28 & & & 4,57 & & 2,85 & 1,99 & 2,79 & & 3,40 & & \\
\hline 9 & & 3,82 & $-2,18$ & & & & & & $-4,22$ & & & 5,30 & & & 5,42 & & 1,30 & & 4,05 & & 3,54 & 2,18 & \\
\hline 10 & & 3,56 & & & 2,80 & & & & & & & 5,53 & & & 10,19 & 2,17 & & & 3,37 & & 3,56 & 1,77 & \\
\hline 11 & & 4,99 & & & 2,24 & & & & & & & 5,60 & & & 14,75 & 3,48 & & & 5,37 & & 2,44 & 2,57 & \\
\hline 12 & & 4,49 & & & & & & & $-2,25$ & & & 4,71 & & & 17,54 & 5,69 & & & 6,51 & & 1,63 & 2,55 & \\
\hline 13 & & 6,87 & & 1,99 & & & & & $-3,37$ & & & 5,52 & 2,04 & & 16,61 & 8,28 & & & 6,71 & & & 3,73 & \\
\hline 14 & & 6,56 & & 2,07 & & & & & & & & 5,42 & & & 13,39 & 8,91 & & & 6,03 & & & 3,43 & \\
\hline 15 & & 7,03 & & 2,09 & & & & & & & & 4,80 & & & 7,66 & 8,18 & $-2,10$ & & 5,21 & & & 3,86 & \\
\hline 16 & & 8,41 & & 2,46 & & & & & & & & 3,85 & & 2,44 & 5,18 & 6,81 & $-2,39$ & & 5,33 & & & 2,73 & \\
\hline 17 & & 6,83 & & 2,37 & & & & & & & & 1,50 & & & 3,14 & 3,88 & & & 3,40 & & & 2,92 & \\
\hline 18 & & 5,55 & 2,99 & 1,41 & & & & & & & & 3,09 & & & 0,38 & 1,68 & & 2,27 & 1,72 & & & 3,78 & \\
\hline \multicolumn{2}{|c|}{ kategória } & & z-score & szín & & \multicolumn{2}{|c|}{ kategória } & & z-score & szín & & \multicolumn{2}{|c|}{ kategoria } & & z-score & szín & & & & & & & \\
\hline szign al & lacsony & abb & $<-4$ & & & \multicolumn{3}{|c|}{\begin{tabular}{|l} 
nem szignifikáns \\
\end{tabular}} & $0-2$ & & & magas & & & $7-10$ & & & & & & & & \\
\hline szign al & lacsony & abb & $-4<-2$ & & & alacsor & & & $2-4$ & & & nagyor & $n$ magas & & $10-15$ & & & & & & & & \\
\hline nincs tic & öbblet & & $-2<0$ & & & közepe & & & $4-7$ & & & extrém & & & $>15$ & & & & & & & & \\
\hline
\end{tabular}




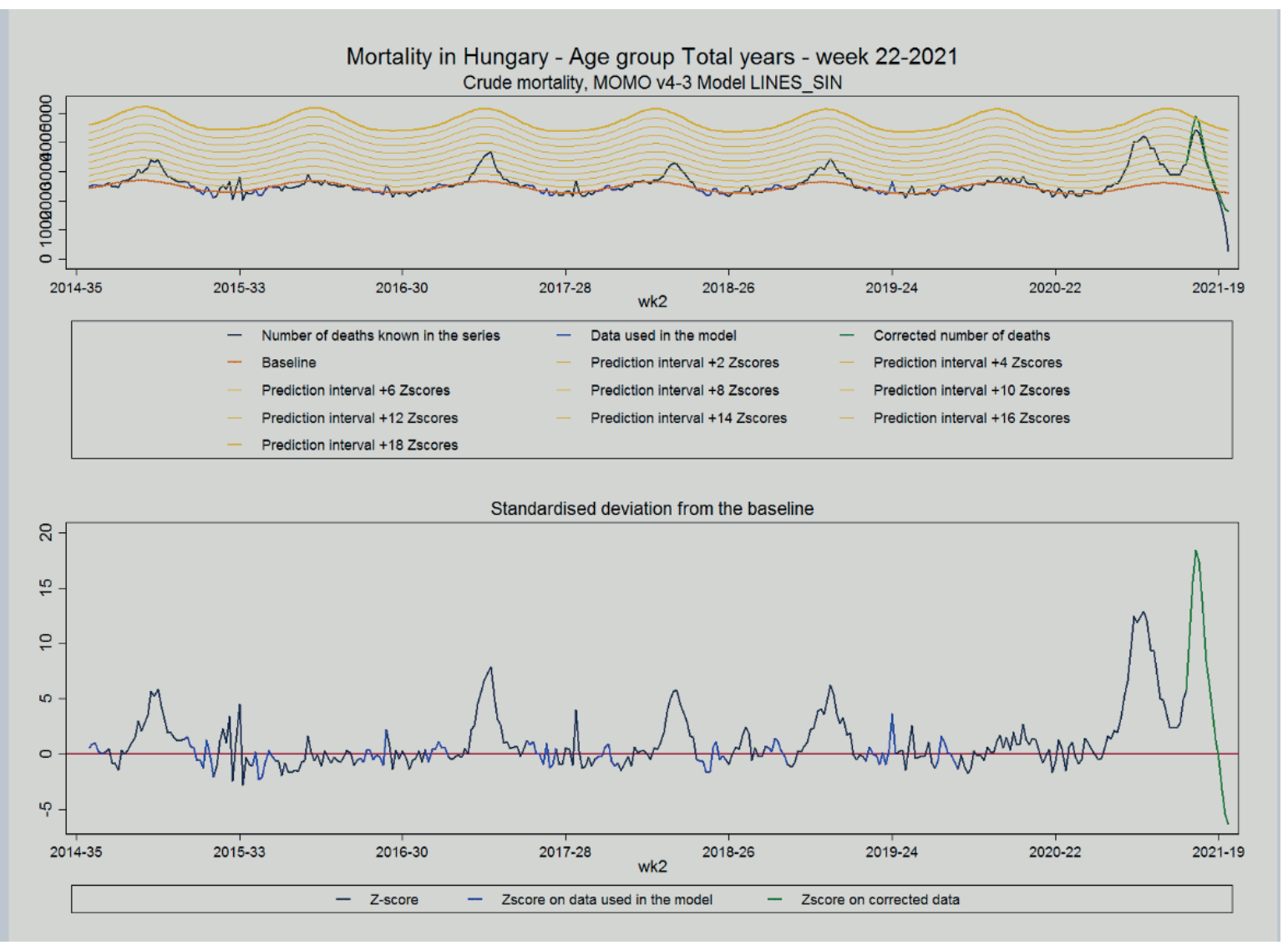

8. ábra: A halálozások heti alakulása Magyarországon 2014. 35. - 2021. 19. hét között esetszámok és eltérés az átlagtól Z-score-ban megadva, teljes népesség

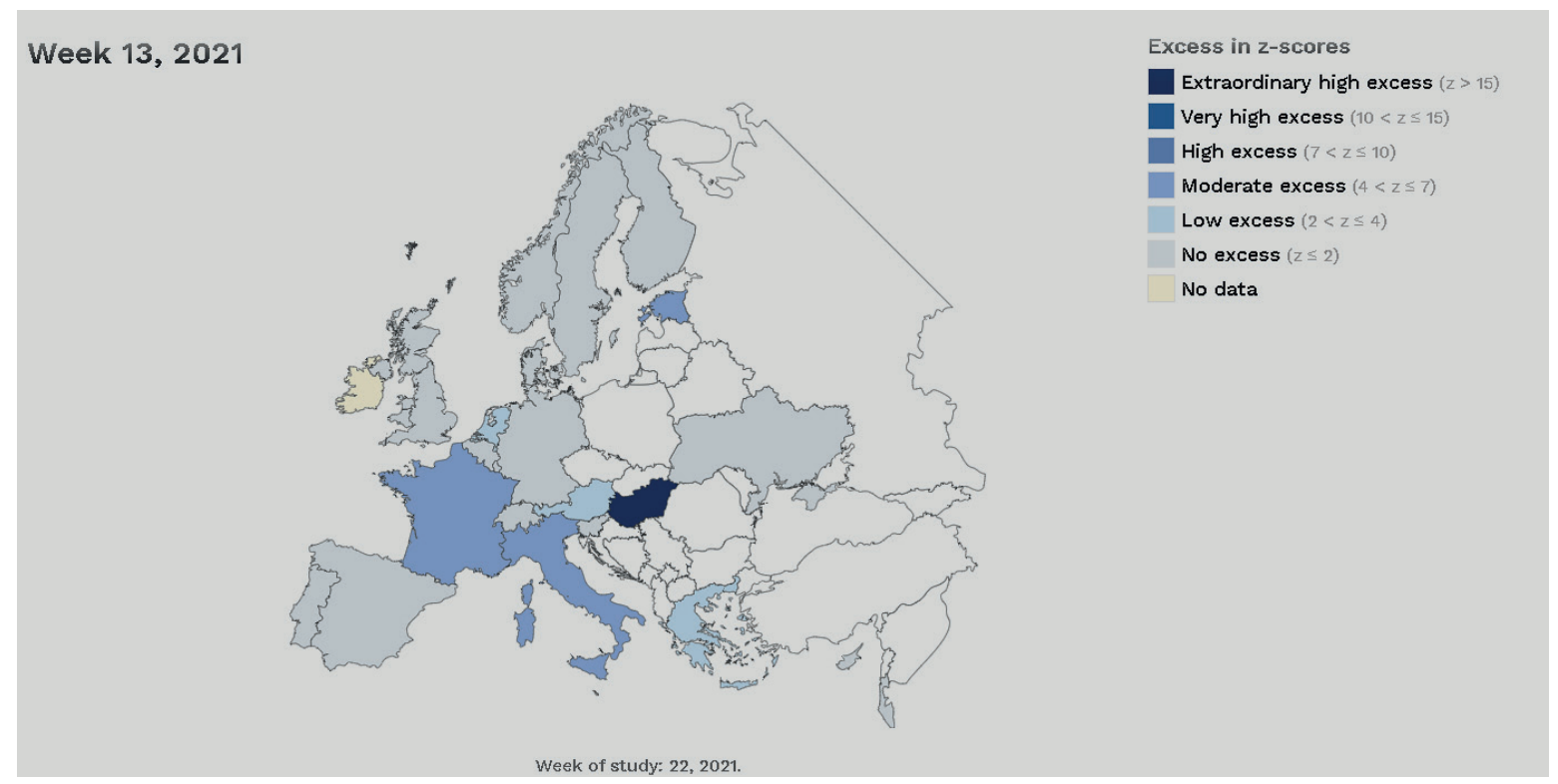

9. ábra: Összhalálozási többlet Z-score érték kategóriákban kifejezve az EuroMOMO hálózatnak adatot szolgáltató országokban 2021. 13. hét 
A 15-64 évesek korcsoportjában nagyobb mértékú többlethalálozást korábban a 2016-2017. téli, valamint a 2018. évi téli influenza idején detektáltak. A 2020. november-decemberi második és a február-márciusi harmadik hullám alatt igen jelentős többlethalálozás volt megfigyelhető, a halálozás az előző évek azonos heti alaphalálozásának standard deviációjához képest 13-19-szer nagyobb eltérést mutatott, ami megközelítőleg 100\%-os többlethalálozást jelentett. Az eltérés elsősorban a 4564 évesek korcsoportjában bekövetkezett többlethalálozásból adódott (10. ábra, 2. táblázat), de a 15-44 évesek körében is kimutatható volt a 2011. 11-18. hét során, a maximumot (9-es Z-score) a 13. héten detektálták.

A 65 év felettiek korcsoportjában 2016-ot kivéve minden évben megfigyelhető bizonyos hetekben, elsősorban a téli influenzajárványok idején, de 2015-ben a nyári hőhullámok idején is szignifikáns többlethalá- lozás. A SARS-CoV-2 vírus okozta pandémia 2. és 3. hulláma alatt az idősek körében a halálozás az előző évek azonos heti alaphalálozásának standard deviációjához képest 12-15-szörös eltérést mutatott (11. ábra).

A 2. táblázat a 2021. február-márciusi 3. hullám részletes hazai adatait mutatja be. Látható, hogy a 4. héttől a 65 év felettiek halálozása emelkedett, a többlet maximuma a 12. héten volt megfigyelhető (Z-score: 15,19; 91,75\%-os többlethalálozás), ami a 18. hétre csökkent le az alaphalálozásnak megfelelő szintre. A középkorúak halálozása a 8. héttől kezdett emelkedni, a csúcsot a 13. héten érte el, amikor a Z-score értéke 18,14-re emelkedett, ami 125,2\%-os halálozási többletet jelentett. Meg kell jegyezni, hogy ez az érték még változhat, mivel az EuroMOMO rendszer korrigált esetszámot vett figyelembe a halálozás időpontja és a regisztrálás közötti időeltolódás miatt.

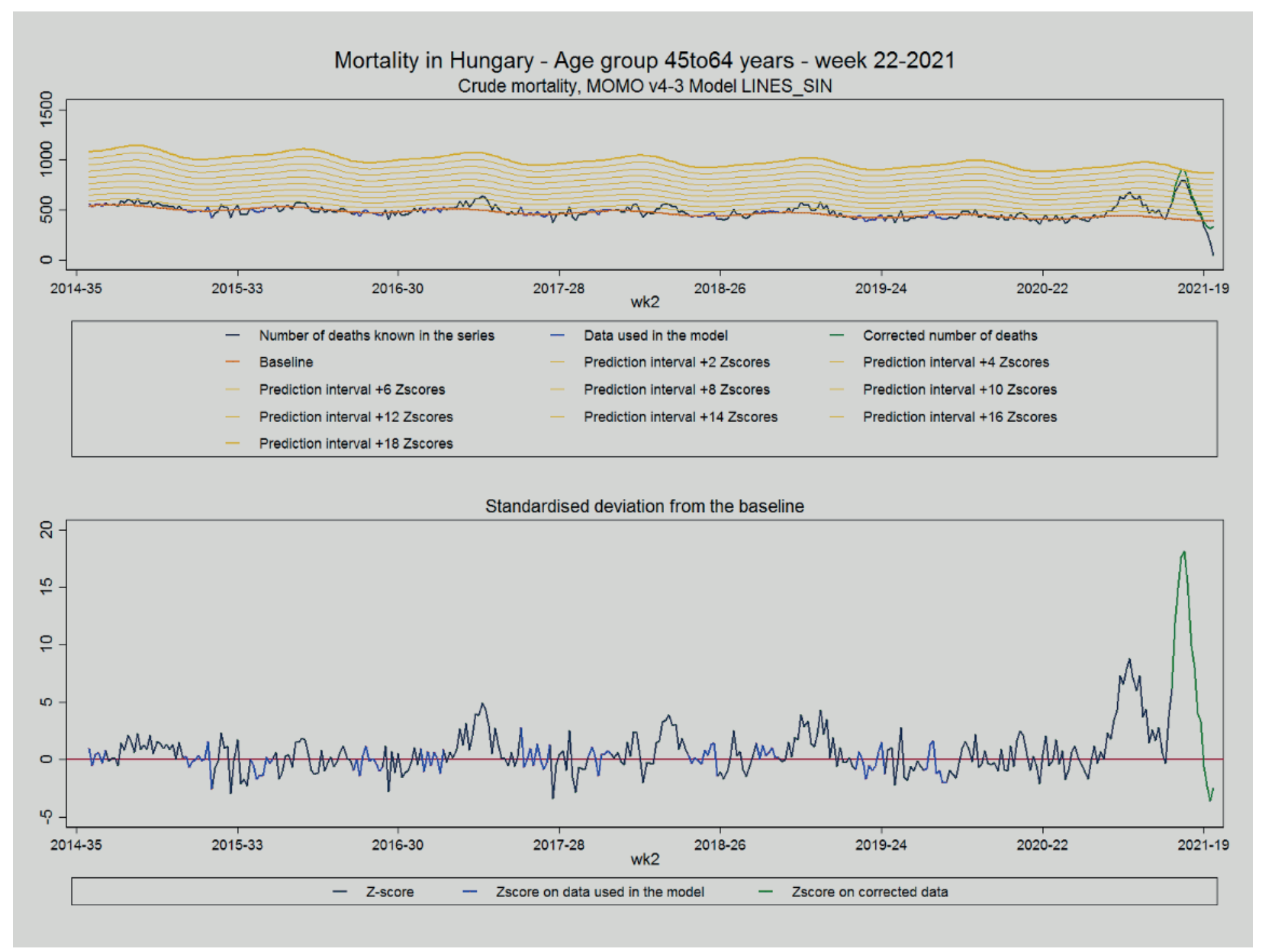

10. ábra: A halálozások heti alakulása a 45-64 éves korcsoportban Magyarországon 2014. 35. hét- 2021. 19. hét közötti esetszámok és eltérés az átlagtól Z-score-ban megadva, teljes népesség 


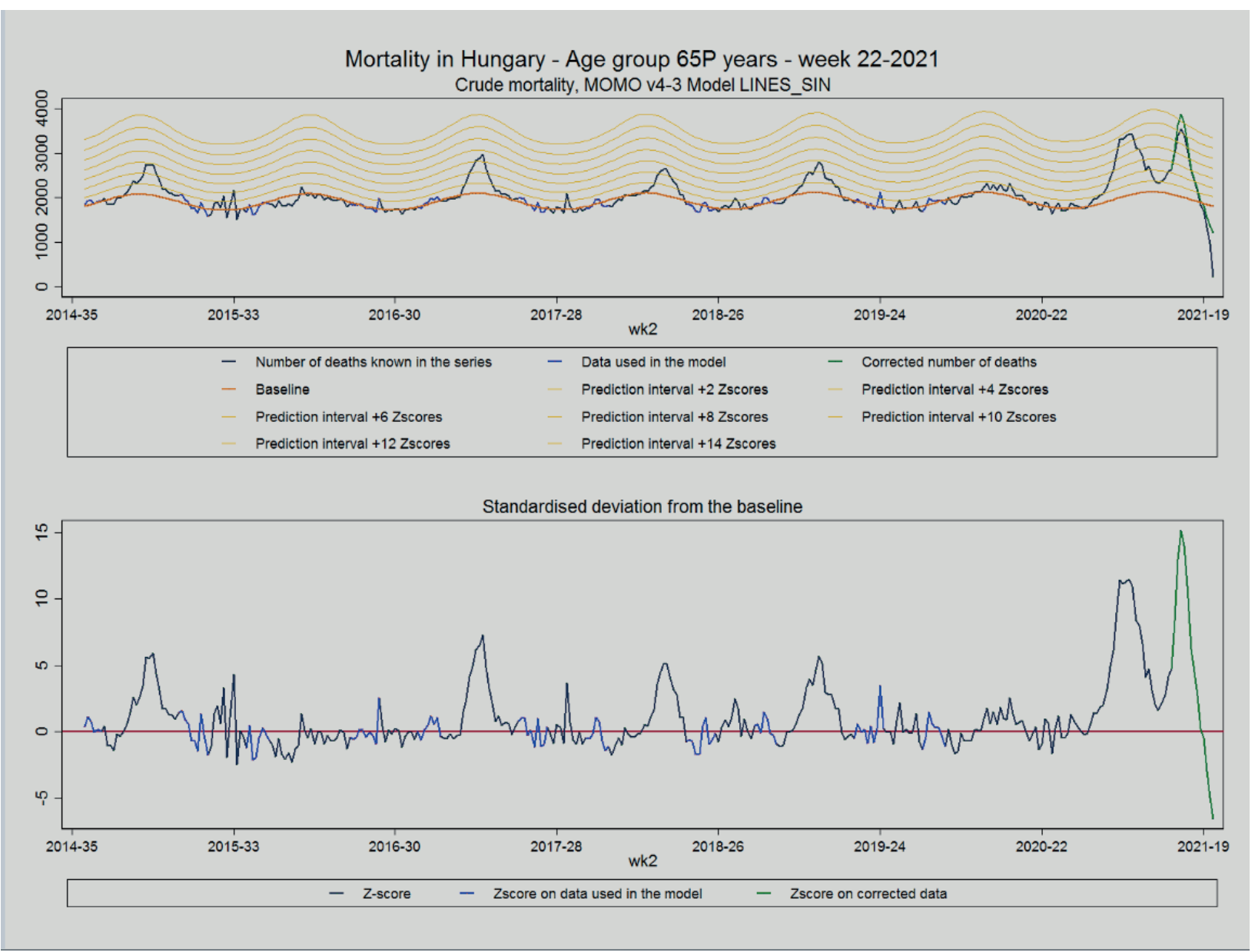

11. ábra: A halálozások heti alakulása a 65 év feletti korcsoportban Magyarországon 2014. 35. hét - 2021. 19. hét közötti esetszámok és eltérés az átlagtól Z-score-ban megadva, teljes népesség

2. táblázat: A heti többlethalálozás alakulása kiválasztott korcsoportonként Magyarországon 2021. 4-18. hét között az EuroMOMO jelentés alapján

\begin{tabular}{|c|c|c|c|c|c|c|c|c|c|c|c|c|c|c|c|c|c|c|c|c|}
\hline 45-64 év & halál éve & \multicolumn{19}{|c|}{2021} \\
\hline 45-64 év & halál hete & 4 & 5 & 6 & 7 & 8 & 9 & 10 & 11 & 12 & 13 & 14 & 15 & 16 & 17 & 18 & 19 & 20 & 21 & 22 \\
\hline 45-64 év & halálesetek száma & 469 & 496 & 433 & 408 & 511 & 560 & 680 & 736 & 787 & 794 & 740 & 619 & 571 & 470 & 444 & 334 & 273 & 180 & 43 \\
\hline 45-64 év & korrigált esetszám & & & & & & & 734 & 819 & 896 & 903 & 813 & 648 & 594 & 490 & 471 & 378 & 339 & 310 & 334 \\
\hline 45-64 év & várt halálozás & 425 & 422 & 419 & 417 & 414 & 411 & 408 & 406 & 403 & 401 & 398 & 396 & 395 & 393 & 392 & 391 & 390 & 389 & 389 \\
\hline 45-64 év & zscore & 1,68 & 2,79 & 0,53 & $-0,34$ & 3,72 & 6,15 & 11,90 & 14,93 & 17,68 & 18,14 & 15,45 & 9,89 & 8,04 & 4,07 & 3,36 & $-0,57$ & $-2,28$ & $-3,62$ & $-2,48$ \\
\hline többlet \% & & 10,35 & 17,54 & 3,34 & $-2,16$ & 23,43 & 36,25 & 79,90 & 101,72 & 122,33 & 125,19 & 104,27 & 63,64 & 50,38 & 24,68 & 20,15 & $-3,32$ & $-13,08$ & $-20,31$ & $-14,14$ \\
\hline >65 év & halálesetek száma & 2380 & 2318 & 2383 & 2440 & 2595 & 2646 & 2994 & 3388 & 3547 & 3417 & 3106 & 2605 & 2388 & 2155 & 1835 & 1700 & 1342 & 958 & 226 \\
\hline$>65$ év & korrigált esetszám & & & & & & & 3068 & 3634 & 3881 & 3680 & 3247 & 2639 & 2417 & 2197 & 1916 & 1830 & 1571 & 1369 & 1218 \\
\hline$>65$ év & várt halálozás & 2128 & 2124 & 2117 & 2107 & 2094 & 2079 & 2063 & 2044 & 2024 & 2003 & 1981 & 1958 & 1936 & 1914 & 1892 & 1871 & 1852 & 1834 & 1817 \\
\hline$>65$ év & zscore & 2,10 & 1,63 & 2,23 & 2,80 & 4,20 & 4,79 & 8,37 & 12,99 & 15,19 & 14,05 & 11,01 & 6,23 & 4,52 & 2,73 & 0,24 & $-0,42$ & $-2,92$ & $-4,96$ & $-6,51$ \\
\hline többlet \% & & 11,84 & 9,13 & 12,56 & 15,80 & 23,93 & 27,27 & 48,72 & 77,79 & 91,75 & 83,72 & 63,91 & 34,78 & 24,85 & 14,79 & 1,27 & $-2,19$ & $-15,17$ & $-25,35$ & $-32,97$ \\
\hline összesen & halálesetek száma & 2907 & 2895 & 2884 & 2924 & 3176 & 3262 & 3773 & 4219 & 4455 & 4330 & 3936 & 3324 & 3040 & 2704 & 2366 & 2079 & 1656 & 1171 & 272 \\
\hline összesen & korrigált esetszám & & & & & & & 3897 & 4531 & 4893 & 4693 & 4138 & 3394 & 3100 & 2777 & 2482 & 2266 & 1964 & 1727 & 1634 \\
\hline összesen & várt halálozás & 2601 & 2593 & 2583 & 2570 & 2555 & 2538 & 2519 & 2498 & 2476 & 2454 & 2430 & 2407 & 2384 & 2361 & 2339 & 2319 & 2299 & 2282 & 2266 \\
\hline összesen & zscore & 2,40 & 2,37 & 2,37 & 2,80 & 4,89 & 5,79 & 10,07 & 15,53 & 17,54 & 17,42 & 13,78 & 8,37 & 6,23 & 3,72 & 1,31 & 0,50 & $-3,23$ & $-5,47$ & $-6,29$ \\
\hline \multirow[t]{5}{*}{ többlet \% } & & 11,76 & 11,65 & 11,65 & 13,77 & 24,31 & 28,53 & 54,70 & 81,39 & 97,62 & 91,24 & 70,29 & 41,01 & 30,03 & 17,62 & 6,11 & $-2,29$ & $-14,57$ & $-24,32$ & $-27,89$ \\
\hline & & \multicolumn{2}{|c|}{ kategória } & & z-score & szín & & \multicolumn{2}{|l|}{ kategória } & & z-score & szín & & \multicolumn{2}{|c|}{ kategoria } & & z-score & szín & & \\
\hline & & \multicolumn{2}{|c|}{ szign alacsonyabb } & & $<-4$ & & & \multirow{2}{*}{\multicolumn{2}{|c|}{\begin{tabular}{|l} 
nem szignifikáns \\
alacsony
\end{tabular}}} & & $0-2$ & & & \multirow{2}{*}{\multicolumn{2}{|c|}{$\begin{array}{l}\text { magas } \\
\text { nagyon magas }\end{array}$}} & & $7-10$ & & & \\
\hline & & \multirow{2}{*}{\multicolumn{2}{|c|}{ szign alacsonyabb }} & & $-4<-2$ & & & & & & $2-4$ & & & & & & $10-15$ & & & \\
\hline & & & & & $-2<0$ & & & $\begin{array}{l}\text { alacsony } \\
\text { këzones }\end{array}$ & & & $4-7$ & & & extrém & & & $>15$ & & & \\
\hline
\end{tabular}




\section{Megbeszélés}

Jelen közleményünkben az összes halálozás miatti többlethalálozás mutató segítségével mutattuk be Európa 23 országában a Sars-CoV-2 vírus okozta pandémia lefolyását 2020-2021. I. negyedéve alatt. A módszert az EuroMOMO Hálózat 2008-2010 között az influenzajárványok halálozásra kifejtett hatásának gyors detektálására fejlesztette ki, azóta értékeli azonos módon, heti rendszerességgel a jelentő európai országok adatait.

Az összhalálozás miatti többlethalálozási mutató alkalmazásának több előnye is van, egyrészt magában foglalja a COVID-19 miatti halálozásokat, másrészt a különböző haláloki kódolásból származó eltérések nem befolyásolják az értékét, mivel az összhalálozást magában foglaló többlethalálozás nem haláloki diagnózison alapszik. Ezen megállapítás jelentőségét megerősítik pl. azok az elemzések, amik a COVID-19 járvány első hulláma lecsengése után készültek. Érdemes kiemelni pl. Beaney és mtsai tanulmányából²azt, hogy a legmagasabb többlethalálozási arányt Spanyolországban és Angliában-Walesben detektálták 2020. tavaszi időszakában, de Spanyolországban a többlethalálozás közel 40\%-a nem COVID-19 fertőzéssel kapcsolatos halálozásként volt regisztrálva. Ezzel szemben Belgiumban, Franciaországban és Svájcban a nem-COVID-19 fertőzéssel kapcsolatos halálozások aránya alacsonyabb lehetett, mint a várt érték. Egy másik tanulmány ${ }^{14}$ öszszehasonlította több európai ország, többek között a korábban említett három ország esetében a COVID-19 mortalitást és az összes halálok miatti többlethalálozást szintén a 2020. évi első hullám idején. Kiemelték, hogy bár Belgiumban volt a legmagasabb a COVID-19 miatti halálozás, de a többlethalálozásban nem állt az első helyen. Az előbbivel ellentétben az Egyesült Királyság, Olaszország és Spanyolország alacsonyabb COVID-19 halálozást jelentett, viszont a többlethalálozás jelentősen magasabb volt. Az első hullám alatt Ausztria és Németország következetesen alacsony COVID-19 megbetegedést, COVID-19 letalitást és az összes halálok miatti halálozás tekintetében a legalacsonyabb arányokat jelentette. Ezt az országok közötti COVID-19 halálozás heterogenitást nagymértékben magyarázza a COVID-19 diagnózis kritérium eltérése, valamint az életkor, a kísérőbetegségek különbözősége és a tünetmentes fertőzöttek aránya. A felsorolt érvek alátámasztják az összes halálok miatti többlethalálozás mutató alkalmazásának célszerúségét. Ez a mutató átfogó képet tud adni a krízis helyzetről, ugyanakkor azokat a haláleseteket is magában foglalja, amelyek az egészségügyi ellátó rendszer megváltozott működéséből adódnak ${ }^{15}$. Másrészt, mivel az összhalálozást magában foglaló többlethalálozás nem haláloki diagnózison alapszik, ezért a különböző haláloki kódolásból származó eltérések sem befolyásolják az értékét.

A többlethalálozást lehet hetenként és egy hoszszabb időszak (pl. év) alatt, mint kumulatív többlethalálozást is értékelni. Ez utóbbit végezték el 29 európai országra vonatkozóan Bogos és munkatársai ${ }^{16}$, az EuroStat adatbázisának felhasználásával. Meg kell jegyezni, hogy az EuroStat a várt halálozást az előző négy év megfelelő heti halálozása átlagaként állapítja meg. Bár ez a referencia érték magában foglalja az előző évek influenzajárványos időszakait, tendenciájában hasonló lefutást mutat az EuroMOMO elemzéshez. Láthatjuk, hogy a COVID-19 járvány az első hullám alatt elsősorban a nyugat-európai országokat érintette, de a mediterrán országok közül Spanyolországban és Olaszországban is magas volt a többlethalálozás, míg a skandináv országok közül Svédország kivételével nem volt szignifikáns többlethalálozás. 2020. nyár végén is elsősorban a mediterrán országokban volt többlethalálozás. A második nagy hullám október végétől január közepéig Nyugat- Közép- és Dél-Európában is jelentős halálozási többletet okozott. A hazai adatok is jelentős, 50-95\%-os heti többletet mutattak november-december folyamán. 2021. február-márciusában elsősorban Magyarországon volt jelentős a járvány hatása. Mivel az elmúlt öt évben január-március között több alkalommal is volt jelentős többlethalálozást okozó influenzajárvány, így ezeket a heteket kizárva az alaphalálozás meghatározásából, a 17. hétig minden héten kimutatható a halálozási többlet. Megjegyezzük, hogy az eredmények még nem tekinthetők véglegesnek a halálozás regisztrációs késése miatt. A 2020. évre számított 7,3\%-os kumulatív többlethalálozás ${ }^{16}$ valószínúleg nem fog módosulni, a 2021-es évre vonatkozó értéket viszont megbízhatóan csak a második félévben, az EuroMOMO rendszerben alkalmazott heti alaphalálozási várt értékek figyelembevételével lehet meghatározni.

A halálozások időbeni értékelése során felmerült a kérdés, elsősorban a svéd járványkezelés kapcsán, hogy a járvány mennyiben járult hozzá a halálozás rövid távú átrendeződéséhez ${ }^{17}$. A heti halálozások adatai szerint a 2020. tavaszi svéd többlethalálozás utáni időszakban azonban nem mutatható ki szignifikáns halálozás csökkenés. Bár az esetek egy része lehetett "elörehozott", az Egyesült Királyság adatai azt mutatták, hogy minden egyes COVID-19 haláleset átlagosan 13 egészségben eltöltött életév veszteséget jelentett ${ }^{18}$. 


\section{Következtetés}

A többlethalálozás mutató alkalmas arra, hogy bemutassa a COVID-19 járvány hatását és lehetővé teszi az országok közötti összehasonlítást. A heti többlethalálozások vizsgálata - különös tekintettel a valós idejü adatokon alapuló értékelés lehetőségére - nagymértékben segíti a krízishelyzetek azonosítását, míg a kumulatív mutatók éves szinten járulnak hozzá az helyzetértékeléshez. Az összes halálozást magába foglaló többlethalálozás mutató nagy előnye az időbeliség, ezért célszerű fejleszteni az elektronikus halottvizsgálati bizonyítványok alkalmazási rendszerét, ami lehetővé teszi a valós idejü adatértékelést, segíti a döntéshozatalt. Az adatok értelmezésénél természetesen vizsgálni kell azokat az egyéb tényezőket is, amik meghatározzák a halálozást mind a direkt COVID-19 megbetegedésekkel kapcsolatos, mind a nem COVID-19 eredetü többlethalálozást.

\section{Anyagi támogatás}

A közlemény megírása anyagi támogatásban nem részesült.

\section{Szerzök hozzájárulása}

P.A. tervezte és összeállította a kéziratot. B.J. elkészítette és értékelte a táblázatokat, eredményeket.

\section{Érdekeltségek}

A szerzőknek nincsenek a tartalmat érintő érdekeltségeik.

\section{Nyilatkozatok}

A szerzők nyilatkoznak arról, hogy a cikk végleges változatát valamennyi szerző elolvasta és jóváhagyta.

\section{Irodalomjegyzék}

1. Karanikolos M, Mckee M. How comparable is covid-19 mortality across countries? Eurohealth 2020; 26:45-50.

https://apps.who.int/iris/bitstream/handle/10665/336263/Eurohealth-26-2-2020-eng.pdf

2. Beaney T, Clarke JM, Jain V, Golestaneh AK, Lyons G, Salman D, Majeed A. Excess mortality: the gold standard in measuring the impact of COVID-19 worldwide? J R Soc Med. 2020 Sep;113(9):329-334. https://doi.org/10.1177/0141076820956802

3. World Health Organization. International Guidelines for Certification and Classification (Coding) of COVID-19 as Cause of Death Based on ICD International Statistical Classification of Diseases.

https://www.who.int/classifications/icd/Guidelines_Cause_of_Death_COVID-19-20200420-EN.pdf

4. WHO. Revealing the toll of COVID-19: a technical package for rapid mortality surveillance and epidemic response. https://www.who.int/publications/i/item/revealing-the-toll-of-COVID-19

5. Villani L, McKee M, Cascini F, Ricciardi W, Boccia S. Comparison of Deaths Rates for COVID-19 across Europe During the First Wave of the COVID-19 Pandemic. Front Public Health. 2020 Dec 11;8:620416. https://doi.org/10.3389/ fpubh.2020.620416

6. Pearce N, Lawlor DA and Brickley EB. Comparisons between countries are essential for the control of COVID-19. Int J Epidemiol. Epub ahead of print 29 June 2020. https://doi.org/10.1093/ije/dyaa108

7. Banerjee A, Pasea L, Harris S, Gonzalez-Izquierdo A, TorralboA, Shallcross L. Estimating excess 1-year mortality fromCOVID-19 according to underlying conditions and age in England: a rapid analysis using NHS health records in 3.8 million adults.MedRxiv2020. https://doi. org/10.1101/2020.03.22.20040287

8. Nørgaard SK, Vestergaard LS, Nielsen J, Richter L, Schmid D, Bustos N, Braye T, Athanasiadou M, Lytras T, Denissov G, Veideman T, Luomala O, Möttönen T, Fouillet A, Caserio-Schönemann C, An der Heiden M, Uphoff H, Gkolfinopoulou K, Bobvos J, Paldy A, Rotem N, Kornilenko I, Domegan L, O'Donnell J, Donato F, Scortichini M, Hoffmann P, Velez T, England K, Calleja N, van Asten L, Stoeldraijer $L$, White RA, Paulsen $\mathrm{TH}$, da Silva SP, Rodrigues AP, Klepac P, Zaletel M, Fafangel M, Larrauri A, León I, Farah A, Galanis I, Junker C, Perisa D, Sin- 
nathamby M, Andrews N, O'Doherty MG, Irwin D, Kennedy S, McMenamin J, Adlhoch C, Bundle N, Penttinen P, Pukkila J, Pebody R, Krause TG, Mølbak K. Real-time monitoring shows substantial excess all-cause mortality during second wave of COVID-19 in Europe, October to December 2020. Euro Surveill. 2021 Jan;26(2):2002023. https://doi. org/10.2807/1560-7917.ES.2021.26.1.2002023.

9. Krelle H, Barclay $\mathrm{C}$ and Tallack C. Understanding excess mortality: what is the fairest way to compare COVID-19 deaths internationally? The Health Foundation.

https://www.health.org.uk/news-andcomment/ charts-and-infographics/understandingexcess-mortality-the-fairest-way-to-make-international-comparisons

10. Weekly death statistics, https://ec.europa.eu/eurostat/statistics-explained/ index.php?title=Weekly_death_statistics\&stable

11. KSH heti monitor, https://www.ksh.hu/heti-monitor/demografia.html

12. EuroMOMO Methods, https://www.euromomo.eu/ how-it-works/methods/

13. Páldy A, Bobvos J: Halálozási anomáliák Európában 2020 első negyedévében - az EuroMOMO rendszer alapján. https://doi.org/10.29179/EgTud.2020.1-2.5-15
14. Corrao G, Rea F, Blangiardo GC. Lessons from COVID-19 mortality data across countries. J Hypertens. 2021 May 1;39(5):856-860. https://doi. org/10.1097/HJH.0000000000002833

15. WHO: The impact of the COVID-19 pandemic on noncommunicable disease resources and services: reference numbers ISBN: 978-92-4-001029-1

16. Bogos K, Kiss Z, Kerpel Fronius A, Temesi G, Elek J, Madurka I, Cselkó Z, Csányi P, Abonyi-Tóth Z, Rokszin G, Barcza Z and Moldvay J (2021): Different Trends in Excess Mortality in a Central European Country Compared to Main European Regions in the Year of the COVID-19 Pandemic (2020): a Hungarian Analysis. Pathol. Oncol. Res. 27:1609774. https://doi.org/10.3389/pore.2021.1609774

17. Robinson $\mathrm{C}$. The truth about Sweden and its $\mathrm{CO}$ VID 19 coronavirus choices. New Zealand Herald. 11 May 2020.

18. Hanlon P, Chadwick F, Shah A et al. COVID-19exploring the implications of long-term condition type and extent of multimorbidity on years of life lost: a modelling study. Wellcome Open Res 2020;5:75. https://doi.org/10.12688/wellcomeopenres.15849.1 